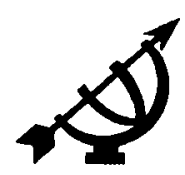

\title{
In the light of the Spirit: the dual nature of the Third Person
}

\author{
David T. Williams \\ Dept. of Historical and Contextual Theology \\ University of Fort Hare \\ ALICE \\ E-mail: WILLIAMS@UFH.AC.ZA
}

\begin{abstract}
In the light of the Spirt: the dual nature of the Third Person

Analogy with physical things and phenomena can be a useful tool in theology. In particular, the vestigia Trinitatis can be used to illustrate the doctrine of the Trinity, even if it is illegitimate to derive it from them. The phenomenon of light has frequently been suggested as a vestigium; in particular its dual nature as particle and wave can serve to illustrate how the Holy Spinit appears both to have the properties of a person, and also acts impersonally.
\end{abstract}

\section{Introduction}

Theology is full of problems which on the surface seem to present irreconcilable truths, and yet which on further reflection are amenable to a solution. Examples of these would be an affirmation of the validity of both infant and adult baptism (cf. Williams, 1987, 1995), or more profoundly, the old chestnut of predestination and freewill (Williams, 1994). What is significant is that in both these cases, as others, it is possible to define each pole of the paradox such that both can be affirmed as valid simultaneously. The classic case of this is the idea of Trinity. On the surface it is impossible to affirm that God is one, yet recognize also the divinity of Jesus and also that of the Spirit along with that of the Father. Again, these seem contradictory, yet early Church history witnesses to the possibility of an intellectually satisfying way of affirming both sides of the paradox. 
Yet, even if this is done, there lurks a suspicion that what is being done is simply playing with words, so that there cannot be a reality behind them. It is quite possible to talk of a "square circle", putting together two quite valid concepts, but knowing full well that the combination cannot possibly exist. Is the same being done with the Trinity?

Here the existence of physical realities which also appear to present mutually contradictory phenomena, requiring a search for a reconciling solution, is very significant for theology. Whereas it could be suggested that reconciling for example divine omniscience and human freewill, or the data on the Trinity, is a solution to an artificial problem, since there is no empirical evidence that anything real lies behind the problem, the case of physical realities, such as electrons and light, is subject to empirical investigation. This means that if the latter can be seen as a valid analogy, such as for the Holy Spirit, it does add to the evidence for the reality of the latter. Whereas apparently contradictory information about the Spirit may lead to a suspicion of actual nonexistence, evidence for his existence being seen as, for example, psychological phenomena, the existence of an analogy in the physical world weakens such a suspicion.

Particularly in the case of the Trinity, a number of physical similarities have been suggested, the vestigia Trinitatis, the reasoning being that the creator would have left some reflection of his nature in what was created. Such may not be valid as evidence for the existence of the Trinity, but may well be accepted as valid analogies, helping understanding of a difficult subject. Although it is not so commonly done, physical analogy is also used for other theological solutions; one example of this is the use of the nature of an electron as both wave and particle to illustrate the dual nature of Christ as divine and human in the incarnation (Bozack, 1993:65-76). Such a procedure has a wide application; the following will concentrate on one aspect of the Trinitarian problem, whether the Spirit is personal or impersonal.

\section{The vestigia Trinitatis}

The basic idea is that if anyone is involved in making anything, it will reflect in some degree the nature of the one who makes it. Biblically, "his invisible nature has been clearly perceived in the things that have been made" (Rom. 1:20). Such are not in any sense divine, but by their nature indicate what God is like; smoke is not fire, but shows what fire is like, as it is caused by fire. Similarly, by looking at the style of writing, it is possible for an expert to deduce a considerable amount of information about the writer. Signatures are of course used in this way; they are totally individual to the signer. 
In this case, the Trinitarian nature of God should be seen in the world. Indeed, Bonaventure sees a Trinitarian unity in the whole created order; creation refiects God throughout (Santmire, 1985:100). Teilhard de Chardin sees creation as a replica of the Trinity (Fortman, 1982:289) Various specific examples of this have been suggested (cf. e.g. Bavinck, 1977:321f). For example, water emerges from a spring, flows through a river to a lake. One substance of water occurs in three ways. A tree is all wood, but is comprised of trunk, roots and branches. Perhaps less crudely, there are three states of matter in solid, liquid and gas, all having the same substance, and there are three dimensions of length, breadth and height.

The classic example of the approach is found in Augustine's de Trinitate, where he examines various possibilities. Not surprisingly, he looks for the Trinity in what he would see as the crown of creation, so in humanity, and then in what he would see as its superior element, so in the mind. $\mathrm{He}$ therefore suggests that the threefold nature of mind as memory, understanding and will is the best picture. Memory, essentially hidden, reflects the Father, active intelligence the Son, and love the Spirit. However, he concludes dissatisfied with his attempt.

The whole attempt to derive the Trinity in this way may be severely questioned. Augustine was working from a premise that the whole Trinity was involved in creation. His view is that the only difference between the Persons of the Trinity is in their internal relationships, and that every external act of God is then an undivided work of the entire Trinity; opera ad extra indivisa sunt. Just as the Trinity, the mind manifests as a unity, not revealing inner structure. It would then be invalid to see evidence of the Trinity in anything in which a structure could actually be observed. Such vestigia are then really impossible. Nevertheless, the Augustinian and Western standpoint has been criticized. It means that reason cannot be used to deduce the Trinity (Bavinck, 1977:328). It may well even be asked how, if external acts of God cannot be the works of distinct Persons, the Trinity can really be known at all (cf. Brown, 1985:285). More pertinently, since the Trinity is based on the Bible, this idea may be questioned Biblically, in that the Bible would appear to attribute specific acts to individual Persons. Thus, as in Colossians 1:16, it would seem that it was the Son only who was the agent of creation (cf. John. 1:10, 1 Cor. 8:6). In fact it is usually the case that if the belief is that operations by God do not reflect the Trinity, then acts of God are "appropriated" to each Person. It may well be asked whether this is not little more than a convenience, and an avoidance of the plain understanding of the Bible. Jüngel (1976:36) even refers to it as a "hermeneutical procedure". Surely, rather, what is revealed is genuine, and really shows the Trinity as it is, even if not necessarily completely. 
A second problem is that it is not certain in what way the Trinity is reflected in the world; it would seem to be fairly arbitrary. Thus although it may well be arguable to see reflections of the Trinity in humanity, and indeed this may well be suggested in the idea that humanity is imago Dei (the image of God) (Gen. 1:26), it is by no means clear how this should be applied. There has been continual discussion as to where, and in what way, the image of God is present in humanity (Clines, 1968:53103). Thus it may well be arguable that humanity reflects the spiritual nature of God, or that it is seen in the dominion over creation, and it has even been suggested (Clines, 1968:58) that this is seen in the physical form of people. Certainly it would not seem to be right to restrict attention to the mind or spirit. Osiander pointed out that the body is also part of the image of God (Moltmann, 1991:62). In this case it would seem to be right to see some vestigia in created things. What is clear is that great care must be taken; although people make coins and indeed something about the nature of people can therefore be deduced (e.g. technical ability, commercial activity and so on), this cannot be pressed. After all, people are not flat metal discs.

Related to this is that just about anything can be justified by this sort of analogy. Examples of threeness may be said to demonstrate the Trinity, but there are many examples of duality which, it could also be suggested, may indicate a binity. Humanity is in two sexes, an individual may be divided into two almost identical mirror images, and so on. Then the fact of four limbs in most animals could perhaps suggest a quaternity in God. It is even perhaps more logical to see the mind in terms of twoness than Augustine's threeness (Brown, 1985:273). Indeed the use of the vestigia is likely to impose ideas of threeness on the Trinity which perhaps should not be there, as Augustine is accused of having done (Gunton, 1990:45).

In the light of such problems, it would seem to be illegitimate to try to deduce a doctrine of the Trinity in this way. The vestigia cannot be used to prove a Trinity. Nevertheless, it would not be illegitimate to seek to illustrate or to clarify the doctrine as deduced from the Bible, and this is what Augustine was trying to do (Bavinck, 1977:325). Aquinas wrote that "once the Trinity is given, analogical reason has its place" (Kelly, 1989: 91). Jüngel (1976:12) in fact suggests that this use of analogy is indispensable. Thus once a doctrine has been accepted, it would then be valid to seek examples of that in creation, and such can well be found

Karl Barth (1975:336f) devotes a considerable section of the first volume of his Church Dogmatics to the question of the vestigia Trinitatis. His view is well known, that no form of natural theology, a deduction about God from nature, is valid, and so for him, scripture is the only valid source for the idea of Trinity. Even illustration of revelation is wrong, as in 
Augustine; all that is permissible is to interpret it. His reason for this is that illustration is a short step from idolatry. The vestigia are even a hindrance as detracting from revelation. He has, however, referred to creation as a "temporal analogue, taking place outside of God, of that event in God himself by which God is Father of the Son", so a "created correspondence" to the Trinity (Barth, 1949:52). This analogy, however, emphatically depends on the prior recognition, from revelation, that God is the creator.

With his stress on the unity of God, Augustine is moving away from the Biblical portrayal. This is always the danger in the use of reason, and so behind Barth's rejection of the vestigia. However, even if they do not give information about the Trinity in a reliable way, analogy is still absolutely essential. Even the picture of Father, Son and Spirit must be an analogy and so even this is not an accurate reflection of the nature of God. The very idea of the Trinity is in fact itself a vestigium, in logic (Barth, 1949: 340 ), an attempt to describe in words, really to clarify, the actual revelation. Different analogies are possible and reflect different aspects of God. Thus to cite an early example, the second Person was pictured as the "word", the logos of God, a picture with Biblical endorsement (John 1). This preserves aspects, such as expression, that "Son" does not. Other pictures are also possible, such as "wisdom", a picture common in the Fathers, such as Tertullian (Fortman, 1982:110). Likewise the Spirit can be reflected by "wind", "breath", or itself "wisdom" (Gelpi, 1984:125). Wells $(1995: 331)$ points out that all the pictures were originally examples of contextualizing, seeking to describe the Trinity in categories understandable at the time. It then becomes essential, in a scientifically orientated world, to relate the Trinity to the ideas of modern science, and when done, conversation between the disciplines, which has been problematic in the past, is encouraged (Gunton, 1991:159).

\section{The problem of the personality of the Spirit}

It has often been remarked that whereas with the second Person of the Trinity, the Son, his personality is readily accepted while the question of his divinity has been hotly debated, with the Spirit, the third Person, the situation is reversed. This is perhaps understandable, since the experience of Jesus was always of a person clearly separate from his Father, but as human, it was hard to accept that he was also fully divine; on the other hand, the experience of the Spirit could easily be understood as that of God, but was not always accepted as that of a person. Of course, once the divinity of Christ was accepted, it was not difficult to accept a third divinity as well; indeed, apart from a few groups such as the Pneumatomachians of the fourth century (Bavinck, 1977: $310)$, the divinity of the Spirit has never really been in doubt. 
But is the Spirit really a person, coequal with the Father and the Son in the Trinity, or is he (it?) the action or power of either the Father or the Son, or of both together, resulting in what amounts to a binity? Such could be the ancient understanding of the term, where persona was the mask through which an actor spoke (Moltmann, 1981:171). In contrast, the modern concept of a person has often been such as to stress discrete individuality, which has led to the rejection of the use of the term in respect of the Trinity by such as Barth or Rahner, who feel that it implies tritheism. However, what makes personality is not so much individuality, as a relationship to other persons (Gunton, 1991:164). In this case referring to the Spirit as a person means the possibility of a relationship with him that is distinct from that with the other Persons; he is then not just a way of speaking of the action of God.

In the early Christian centuries, when the doctrine of the Trinity was in the process of formulation, some people believe that "... orthodox theologians recognized ... that direct scriptural evidence for the deity of the Holy Spirit as a distinct hypostasis was hard to find" (Lampe, 1983: 217). It may be suggested that the precise doctrine of the Spirit was actually strongly influenced by the development of the doctrine of the Son (Webster, 1983:4); this would include his personality.

There is in fact little real evidence in the post-Biblical writings of the early Church for belief in a Holy Spirit really distinct from Father and Son; indeed the full deity of the Spirit was not declared an article of belief until the council of Constantinople in 381 AD. Even then, Basil never referred to the Spirit as "God" or used the term homoousios, preferring homotimos (of equal honour) or homodoxos (of equal glory). Could the early Church be seen as binitarian, as some believe (Mackey, 1983:135)? Is Trinitarian belief something that was dragged into orthodoxy in the development of belief concerning Father and Son, so a full statement of the personal divinity of the Spirit felt necessary to avoid a second kind of subordination after Arianism (Mackey, 1983:137), or is this real, and a true interpretation of the Bible?

What is very clear is that the Bible, whether in Old or New Testaments, regards the action of the Spirit as the action of God. It is often pointed out, for example, that when Annas and Sapphira lied to the Spirit, it was lying to God (Acts 5:3,4). More to the point here, however, it is possible to refer to the Spirit as divine insofar as acting for God, just as in Old Testament action the messenger could be regarded as having the authority of the one who sent him (Johnson, 1961:5), so would be seen as an extension of his personality. In this case the Spirit need not be viewed as personal. 
The full personality of the Spirit is suggested by texts which mention Father, Son and Holy Spirit together. Gregory of Nazianzus, Athanasius and Basil make their main appeal to the doxologies (Lampe, 1983:218). Specifically Matthew 28:19 and 2 Corinthians 13:14 place the three Persons together such that an equality and a separate identity of each would seem to be logical; neither however, demands this. In the story of Jesus' baptism, both the voice of the Father and the appearance of the Spirit in bodily form as a dove were also observed. But was the Spirit simply the power of the Father? There are also texts such as 1 Peter 1:2, 2 Thessalonians 2:13 and John 14:26, but these are all amenable to this form of binitarianism.

Wainwright (1962:248f) also notes considerable evidence for a triadic belief in the New Testament. Luke, hardly surprisingly due to his interest in the Spirit, both opens (Luk. 1:31-5) and closes (Luk. 24:49) his gospel by referring to all three Persons. Triadic reference is common in Paul, and the three most structured epistles, Romans, 1 Corinthians and Galatians, show evidence of a triadic structure based on Father, Son and Holy Spirit. Nevertheless, this does not prove that all three are coequal Persons, but on the contrary there are striking omissions, such as reference to the Spirit in re-creation in Revelation 21 and 22 and from Paul's favourite greeting "from God the Father and the Lord Jesus Christ" (Rom. 1:7 etc.).

In a sense, it is very natural to regard the Spirit as simply the activity of God the Father or of Christ. The very word, whether in English or in most other languages, suggests impersonality. Unlike the experience of Christ, the Spirit is always experienced in an impersonal way; there is no entity in clear distinction from the person in whom the Spirit is acting. Moltmann (1992:10) notes that the records of the experience of the Spirit use impersonal words. The baptism and filling with the Spirit almost demand impersonality, and even the phenomena at the day of Pentecost, the fire and the wind, are far from experiences of a person.

References such as Acts 2:4 are hard to reconcile with the personality of the Spirit. How can the disciples be filled with a person? They can be influenced by one, guided by one, even inspired by one, but filling is inappropriate. The same is true of "receiving" the Spirit (e.g. Acts 8:15) and other activities, notoriously being baptized in the Spirit (e.g. Acts 11:16). The Pentecostal experience is not of meeting a person, but of being filled with power; this is true of the Acts 2 account and of Jesus' enactment of the giving of the Spirit in John 20:21, where he breathed on the disciples. It is also noticeable that while the New Testament speaks of Jesus as receiving and accepting worship, and of invoking Jesus (e.g. Acts 7:59, Rev. 22:20), so effectively praying to him, a practice which 
certainly occurred in the early Church, yet this is never the case for the Spirit, which would be expected to be the case if he were a person in the same way as Christ.

There is likewise no compelling reason for personalization of the Spirit in the Old Testament. In both Testaments, the Spirit even lacks a personal distinction from God. Whereas the personal nature of both Father and Son is clear in that there is a two way relationship between them, there is no reciprocity in the interaction between Father and Spirit (Wainwright, 1962:220)

Indeed it may well be argued that essentially the Spirit cannot be fully personal, for that would make him into a second Son. That has always had to be avoided, firstly by careful definition of the origin of the Spirit; in the East this was said to be through the Son, and in the West from Father and Son. Secondly, in contrast to the "generation" of the Son, the Spirit was said to "proceed"

Yet, classical Christian theology insists that the Spirit is indeed a person. Firstly the word itself does not demand impersonality, as there are such things as spirits which would seem to have separate, personal identity; 1 Kings 22:21 describes one of these in apparently personal terms. Secondly, despite the fact that "spirit" in Greek is a neuter word, so suggesting impersonality, some passages in John, such as $16: 13$, quite clearly refer to the Spirit by means of a masculine pronoun. Moreover, and perhaps an explanation of these, John refers to Jesus' promise to send another advocate, a comforter. Now the word for this, parakletos, has a masculine form, and in any case Jesus refers to the sending of another, so distinct from himself, so if he is personal it is a reasonable inference that so is the coming one. This is the same argument as that from the equality of the Persons; as Father and Son are personal, so is the Spirit (Gelpi, 1984:117). However, personality is surely not a feature of essence, but a relation or attribute. It must, however, be noted that elsewhere in John, for example in John 14:17, neuter pronouns are used in reference to the Spirit, and where a masculine pronoun is used elsewhere, as in John 16:7, its gender is governed by that of parakletos. It must incidentally be noted here that, despite the apparent impersonality of the Spirit in the Old Testament, the word is linguistically feminine; Hebrew, however, lacks a neuter. At the same time, in Latin, spiritus is masculine, and so implies personality; such could perhaps have influenced Latin theology.

The third reason for seeing the Spirit as personal is the main one. It is argued that very frequently the action attributed to the Spirit is that of a person. He teaches (John 14:26), convinces (John 16:8), guides (John 
16:13), speaks (Acts 8:29), calls (Acts 13:2) forbids (Acts 16:6), intercedes (Rom. 8:26) and so on. He can be lied to (Acts 5:3), tempted (Acts 5:9), resisted (Acts 7:51), grieved (Eph. 4:30), and blasphemed (Mat. 12:31, a text that particularly indicates a real distinction from the Son). Olyott (1979:49) also suggests that there are a number of texts (Acts 15:28; Mat. 28:19; Luk. 14:14; Acts 10:38; Rom. 15:13; 1 Cor. 2:4) which become meaningless if "Spirit" were replaced by "power", particularly in the case such as 1 Corinthians $2: 4$ "in demonstration of the Spirit and power". On the other hand, just as the link with the first two Persons can suggest personality, so this can suggest impersonality.

Personal and impersonal; there are valid arguments for each. The preceding is by no means exhaustive. But is this a contradiction? is it necessary to choose? On the contrary, it would seem that it is necessary to affirm both aspects and to seek to understand how these can both be true.

\section{The analogy of light}

It is here that the use of the vestigia, of analogy, comes into play, for there is indeed a very similar situation existing in nature to that of the Holy Spirit. The understanding of the nature of light provides a similar paradox, and so, by analogy, provides a suggestion as to the nature of the Spirit. Light presents a duality between wave and particle which is analogous to the Spirit acting in both a personal and an impersonal way. The essence of the physical paradox is that in some circumstances, light behaves as an electromagnetic wave, exhibiting similar phenomenon to other radiations in the spectrum, but of specific frequencies and corresponding wavelengths. The wave nature is seen clearly in such phenomena as refraction, diffusion and particularly interference, demonstrated by experiments such as Young's (Haken, 1981:41). On the other hand, light also behaves in such a way as would be explained by seeing it as discrete elements, almost particles, known as "photons". Again there is a well accepted set of evidence to support this, in particular the photoelectric effect and the Compton effect (Haken, 1981:57). Now such evidence is, at least on the surface, mutually contradictory; a single entity cannot behave as a wave and also as a particle. Nevertheless, there must be a way to explain how both sets of data are simultaneously applicable to a single thing. As regards light, this is indeed the case, and done through the quantum theory.

The choice of light as an analogy for the Spirit is not arbitrary. The Bible does contain a number of analogies to the Spirit. Wind or breath is common, and is reflected in that a common word is used in Greek, Hebrew and in many other languages. Yet this does not exhaust the 
possibilities. Oil and water come naturally to mind, the former due to its use in anointing (Ex. 29:7) and in healing (Jas. 5:14), the latter because of baptism and in drinking (John 7:38). Fire is another possibility, which along with wind symbolized the descent of the Spirit on the day of Pentecost (Acts 2:3). Both evoke the idea of power, which is central to the work of the Spirit. It is a very small step from the analogy of fire to that of light; in the ancient world, fire was the only practicable source of light. Moltmann, with his view of the universal influence of the Spirit (although John 14:17 notes that the world cannot receive him or know him), is naturally attracted by the analogy. He comments that the use of light as a metaphor for God is ages old (Moltmann, 1992:281). Certainly it is an Old Testament picture, as in Psalm 27:1 and Micah 7:8. It is not surprising that it was early used as analogous for the Trinity by Tertullian. Specifically, light has commonly been used as an analogy for the Spirit, such as by several fourth century Fathers, notably Basil and Gregory of Nazianzus. They were attracted to the picture as they perceived an equality of emitter and emitted. In the Bible, Revelation 4:5 equates the torches of fire round the throne of God with the "seven spirits of God". A striking case is the brightness of Moses' face (Ex. 32:30; 2 Cor. 3:7 f.). Although the giving of the law is contrasted with the dispensation of the Spirit, the inference is that the experience of Moses was caused by that same Spirit (2 Cor. 3:16-7).

Many of the references to light as a symbol for life can also be seen as applying to the Spirit, such as 1 Thessalonians $5: 5$, referring to Christians as children of light. Light is a means by which we see; it is also a means of transferring energy from the transmitter, energy which is detected by the eye in sight. It may also, therefore, quite significantly, be a means of communication, for the waves may be modified in amplitude or frequency in accordance with the message being communicated. This is a reasonable analogy for the Spirit, who helps Christians to understand spiritual truth (John 16:13), to be "enlightened", and also is the means by which the power of God becomes available (Acts 1:8). From a Trinitarian perspective, it is perhaps no accident that we perceive things mainly by two senses, hearing and sight. While the former can refer to the Word, the second Person, the latter can refer to the third, the Spirit. It is by these that we know what we do of God.

Physically, light is produced without a diminution of the substance of the source (although it does require energy). This is very different from the birth of a son, which is due to a change in the parents. It is for this reason that in the case of the Trinity, the Son is defined, following Origen, as coming by an eternal generation, so without change in God. The metaphor of light does not suffer from this problem, so again can fittingly be 
used as an analogy for the Spirit. Light is emitted as a process, and the Spirit eternally proceeds.

Moreover, just as spirit is almost by definition immaterial, so light likewise is immaterial and requires no material medium for its transmission. When the wave nature of light was originally investigated, it was supposed that there was such a thing as a "lumeniferous ether" which pervaded the universe and was the means by which light travelled as an oscillation in that medium. Later research, however, clearly demonstrated that the speed of light was a constant, irrespective of the direction of travel, indicating that such an ether did not exist. It may incidentally be noted that the speed of light is one of the physical absolutes, as it can never be exceeded. The action of the Spirit likewise provides an absolute in a world which is taken up with relative assessment of such as moral values.

The danger with any analogy is that it can be pressed too far, but it could perhaps be noted that there are seven colours in the visible spectrum, and enigmatic references to the seven spirits of God (e.g. Rev. 1:4, 5:6). It is also the case that whereas light does not harm (except to the eye if too bright), other parts of the electromagnetic spectrum, such as gamma rays, are less benign. Evil spirits also exist.

Specifically, the dual nature of light as both a wave motion and particle can provide some help in understanding how the Spirit can be simultaneously personal and impersonal. Whereas a wave is very much an action of its source, so is "impersonal", a particle is not affected by it once it has been emitted, so relates to what it falls upon in a "personal" way, independent of the source.

On the one hand, one side of the nature of light is its particular nature, seeing that it comprises discrete and separate photons. These are particles with a distinct identity from each other, such particular nature being seen in that they even have a distinct spin, something impossible for a wave motion. Although they come from one source, they act independently of that source. Incidentally, electrons also behave as particles with spin, have a mass, and also exhibit the characteristics of a wave. An individual photon will then have an effect on one particular atom, and on no others; this can be viewed as analogous to the action of the Spirit who guides and speaks to Christians as individuals, so to one in one way, to another in a different way, and gives gifts to Christians on a totally individual basis (1 Cor. 12:7 f.). Such unpredictability is evidenced physically at the subatomic level. The Heisenberg Uncertainty principle is that it is impossible to know everything about an electron or a photon, as the very attempt to measure position or speed inevitably 
changes them in an unpredictable way. Such a vestigium thus includes the idea of freedom, so characteristic of God, an aspect usually absent from other analogies.

It is at an atomic level that the particular nature of light is evident, and on the individual level that the Spirit is seen as a person. The difference is that whereas a single photon is very small and with little power, the action of the Spirit on an individual is by no means small, but because God is infinite, the experience of the Spirit is that of God, and not a part of him.

In distinction from this, light is seen as a wave on the supra-atomic level, so is our normal experience. Here, the wave nature of light provides a reasonable analogue for the impersonal action of the Spirit. Rooms or other spaces may be filled with light, objects may reflect, absorb and retransmit it. Growth, especially in plants, is dependent on it. The pictures of a Christian being filled with the Spirit (Eph. 5:18), being baptized, and even producing the fruit of the Spirit (Gal. 5:22) show a similarity to this. Waves by their nature as a process cannot be localized as can a material object (Bozack, 1993:73). The omnipresence of God (e.g. Ps. 139) can readily be pictured as analogous to the pervasiveness of light. On the other hand, light can also be intensely localised, as in the case of lasers; the Spirit's action can be very specific. God acts on individuals, and in our individualistic society we tend to assume that that is all, but there is surely a place to see the action of God in society, even in churches, in a less personal way. Would it be valid to see this in terms of a Christianization of society, the adherence to Christian norms and standards by groups as a whole? Such may be present even where the majority deny personal faith; God does restrain wickedness, at least to some degree (2 Thess. 2:6). On the other hand, it may tragically be absent in a group even where most claim to be Christian.

There is no question of light or electrons changing from one form to another, but they always have both sets of characteristics. A given situation will emphasize one aspect (Bozack, 1993:73), but the other will still be present. All that can be said is that one will tend to predominate. Thus in the case of light, it may be treated simply as a wave, whereas an electron may usually be seen as a particle. Perhaps the same is true of the Spirit, who may be generally seen in a more impersonal manner, but in some circumstances is clearly personal. Both are Biblical; the only question is which is fundamental. In fact the same is true of human beings, who are considered as persons, but who may also act in a distinctly impersonal way. People may simply provide labour, and in that situation have no element of individuality or of choice, yet in a normal situation the prevalence is of both over impersonal activity. The same is 
even true of Jesus, who was clearly experienced as a person. Salvation is achieved for the Christian in an intensely personal way insofar as the giving of eternal life is through a personal relationship with Christ, a union with him (Rom. 6:4). Yet the other side of the process of salvation, the atonement for sin through the sacrifice on the cross can perhaps better be seen as impersonal insofar as he died for the sins of the whole world (1 John 2:2).

Thus all, people, light, and so also the Spirit, exhibit both personal and impersonal characteristics; the most that can be said is that there is an emphasis on one aspect or another, depending on the situation. Such an emphasis is particularly clear in the nature of light as wave or photon and is evidenced in other elements which also have such a duality. Commenting on this duality, Ditchburn (1976:700) writes "... the limiting theory for matter is a particle theory, and the limiting theory for radiation is a wave theory".

If this suggestion is correct, it does not involve any reformulation of the traditional statement of the Trinity; there is no reason to deny that the Spirit is personal, indeed Biblical evidence supports this. However, there is here an accommodation to the fact that the action of the Spirit can be, and even is usually, impersonal. What must be emphasized is that the desire is to understand the relevant material for the Trinity, and in this case, the personality of the Spirit, in a way more consistent with the Biblical material.

\section{Conclusion}

In conclusion, it might just be observed that the behaviour of light is influenced by the nature of the physical situation. It is bent when passing between air and glass, or may be reflected, dimmed or even totally excluded. In his omnipotence and freedom as God, the action of the Spirit likewise relates to the situation in the world or the Church. The Spirit may be quenched (1 Thess. 5:19), so his light withheld, but more positively, may be more evident in churches that seek to experience him or in a society where people long and pray for revival. Optical instruments have to be made with great care and precision if the light is to do what is intended, and perhaps the lesson for the Christian Church, both as a group and as individuals, is that we too need to take our Christian faith and activity much more seriously if we are to see the workings of the Spirit in a way which we desire.

\section{Bibliography}

BARTH, K. 1949. Dogmatics in outline. London : SCM 
BARTH, K. 1975. Church Dogmatics. Vol. 1(1): The doctrine of the word of God Edinburgh : Clark

BAVINCK, H. 1977. The doctrine of God. Edinburgh : Banner of Truth

BOZACK, M.J. 1993. Physics in the theological seminary. Journal of the Evangelical Theological Society, 36(1):65-76

BROWN, D.W. 1985. The divine Trinity London : Duckworth

CLINES, D.J.A. 1968. The image of God in man. Tyndale Bulletin, 19:53-103.

DITCHBURN, R.W. 1976. Light. Vol. 2. 3rd ed. London: Academic Press.

FORTMAN, E.J. 1982. The triune God: a historical study of the doctrine of the Trinity Grand Rapids : Baker.

GELPI, D.L. 1984. The divine mother: a Trinitarian theology of the Holy Spirit. Lanham, MD : University Press of America.

GUNTON, C 1990. Augustine, the Trinity and the theological crisis of the West Scottish Journal of Theology, 43(1):33-58.

GUNTON, C.E. 1991. The promise of Trinitarian theology. Edinburgh : Clark.

JOHNSON, A.R. 1961. The one and the many in the Israelite conception of God. 2nd ed. Cardiff : University of Wales Press.

JUNGEL, E. 1976. The doctrine of the Trinity: God's being is becoming. Edinburgh \& London : Scottish Academic Press.

HAKEN, H. 1981. Light. Vol 1: Waves, photons, atoms. Amsterdam : North-Holland

KELLY, A. 1989. The Trinity of love: a theology of the Christian God. Wilmington, Delaware : Michael Glazier

LAMPE, G.W.H. 1983. God as Spirit: the Bampton lectures 1976. London : SCM

MACKEY, J.P. 1983. The Christian experience of God as Trinity. London : SCM.

MOLTMANN, J. 1981. The Trinity and the Kingdom of God: the doctrine of God London: SCM.

MOLTMANN, J. 1991. History and the triune God: contributions to trinitarian theology. London: SCM

MOLTMANN, J 1992 The Spirit of life: a universal affirmation. Minneapolis Fortress.

OLYOTT, S. 1979. The three are one. Darlington : Evangelical press.

SANTMIRE, HP. 1985. The travail of nature: the ambiguous ecological promise of Christian theology. Philadelphia : Fortress.

WAINWRIGHT, A.W. 1962. The Trinity in the New Testament. London : SPCK

WEBSTER, J. 1983. The identity of the Holy Spirit: a problem in Trinitarian theology Themelios, 9(1):4-7.

WELLS, H.G. 1995. Trinitarian feminism: Elizabeth Johnson's wisdom Christology Theology Today, 52(3):330-43

WILLIAMS D.T. 1987. The baptism of repentance: a further factor in the infant baptism debate. Theologia Evangelica, 20(1):37-49.

WILLIAMS, D.T. 1994. Jeremiah's call and predestination. South African Baptist Journal of Theology, 3:47-60

WILLIAMS, D.T. 1995. The baptism of anticipation. Religion and Theology, 2(1):7286.

Key concepts:

light as analogy

personality of the Holy Spirit

Trinity

Vestigia Trinitatis 


\section{Kernbegrippe:}

Drie-eenheid

lig - analogie van

persoon van die Heilige Gees

Vestigia Trinitatis 